\title{
Validation of RAPD and ISSR Markers Used for Sex Determination in Date Palm Grown under Sudan Conditions
}

\author{
Ismail A. Mohammed*, Israa A. Mohamed \\ Department of Botany and Agricultural Biotechnology, Faculty of Agriculture, University of Khartoum, \\ Khartoum North, Shambat, P.O. Box 32, Postal Code 13314, Sudan
}

\begin{abstract}
Date palm is one of the most important economical crops in the world. Sex determination of date palm in early stage is a prerequisite for breeding and cultivation. The aim of this study is to validate RAPD and ISSR markers for sex identification of date palm genotypes grown under Sudan conditions. DNA was extracted from ten seedlings and five male and female plants using CTAB method. Eight primers, six RAPD and two ISSR primers were examined for their validation in sex determination of date palm genotypes. PCR amplification was performed using these primers. Four RAPD primers OPA02, OPJ-09, RD A02 and RD A21 were amplified male specific band with size of 1000, 1100, 1000 and $1400 \mathrm{pb}$ respectively, while ISSR markers could not. The specific bands were observed clearly among all male genotypes and absent in female samples unknown samples irrespective of genotypes. Our results could be useful for sex determination of date palm sex in seedling stage and would promote date palm cultivation and production.
\end{abstract}

Key words: Date, DNA markers, Male and female identification, Northern Sudan

\section{Introduction}

Date palm (Phoenix dactylifera $\mathrm{L}$ ) is diploid $(2 n=36)$, monocotyledonous plant [1], considers an important member of the family Arecaceae which contains 200 genera and 500 species [2]. It is native to North Africa and the Middle East and now distributed in Australia, India, Pakistan, Mexico, Southern Africa, South America, and the United States [3]. Date palm is a dioecious plant species, flowers are unisexual where females and males found on separate plants [3]. Female plants only can produce fruits, where male plants can be used as resource of pollen grains. Date palm fruit contains high nutritional value including vitamins, minerals and rich in sugar in contradictory to proteins and fats [4]. Additionally leaves and stems of date palm trees can be used as a shelter and animal foods [4]. In Sudan date palm mainly

\footnotetext{
* Corresponding author: Ismail A. Mohammed,
} ismaildamer@gmail.com

(cc) BY-NC-ND $\odot 2019$ I. A. Mohammed et al., published by De Gruyter Open. This work was licensed under the Creative Commons Attribution-NonCommercialNoDerivs 3.0 License cultivated in Northern parts of Sudan for more than 3000 years with some existence in Kordofan and Darfur [5]. There are many varieties have been cultivated in Northern States including BARAKAWI ,GONDALLA, BIT TAMOUD, KULMA, ABDELRAHIM ,TUNISI JAW, MISHRIG/ WAD LAGGAI, WAD KHATEEB and MEDINA. The total production of both dry and soft dates in Northern States was estimated by 182000 tons of annual production [6].The sex of plants is important in planting of date palm plant; hence, it is difficult to differentiate between male and female plants phenotypically before flowering which takes 4 to 5 years. One male is capable of pollinate $90-100$ of females in the field [7]. Morphological identifications can be carried out only by the flowers of the tree using several specific features in any sex including the long of stamens [8]. Therefore, the sex determination in the seedling stage is very important for breeding. There is a lack of information regarding the genetics of date palm. Several cytological studies have showed heteromorphic chromosome pair in male plants and different appearance of sexual chromosomes 
in date palm [7]. Although the results were useful to distinguish between male and female date palm, and recently DNA fingerprinting techniques have been considered as reliable and quick methods for sex determination in date palm plants [8]. Several kinds of DNA markers are now widely used in evaluation of genetic diversity as well as sex determination in plants.

Random Amplified of Polymorphic DNA (RAPD) is a dominant, PCR based marker used to detect random amplified polymorphism in DNA [9]. RAPD was developed by [10], using single primer with arbitrary nucleotide sequence for detecting the polymorphism in the specific nucleotide sequence. RAPD primers have the ability to detect the polymorphism and gave a reproducible result [11]. It has been used in the genetic diversity studies in economically important food crops such as wheat [12], Rice [13], Sorghum [14]. Several studies have shown the effectiveness of RAPD marker in the term of detecting the polymorphism between and among different populations [15].On the other hand RAPD marker has been used to determine the sex in many dioecious plants such as Carica papaya $L$ [16], Salix viminalis $L$ [17] and Simarouba glauca [18]. In date palm RAPD was used for genetic diversity studies [19] and sex determination [20]. Date palm genome has a region linked to gender which had been identified a few years ago, in this region there are sex determination sequences [21]. Date palm is heterogametic sex (XY) in male over and above there is significant polymorphism in the alleles of male and female which can be helpful in the process of sex determination [22]. XY chromosome and heterogametic male's theory were supported experimentally and had revealed that males were heterozygote in three loci that are linked to sex [23]. A previous study illustrated methods for sex-determination of a date palm plant using sex chromosome. The sex of a date palm plant may be genetically determined by presence or absence of the date palm SRY [24].

Inter simple sequence repeats (ISSR) is a dominant marker depends on the polymerase chain reaction (PCR) using one primer complementary to a target microsatellite [25]. In ISSR marker, the reaction begins in two identical microsatellites repeat regions (16 - 25 bp long) oriented in opposite direction [26]. The ISSR considered as an ideal molecular marker because it's a hold the features of AFLP markers and simple sequence repeats (SSR) [27]. ISSR marker has been used widely to assess genetic diversity and genome analysis in plants because it is a simple, easy, and quick assay to perform [28]; [29]. Previous reports showed the useful of ISSR marker for genetic diversity evaluation among date palm genotypes [30, 31]. The results of using IS A02 and IS A71 marker were very promising, the banding pattern profile provide a clear bands with different base pairs long giving a strong determination of the sex [31].

The main objective of this study is to revalidate a number of RAPD and ISSR markers for sex determination of date palm genotypes grown under Sudan conditions.

\section{Material and Methods}

Plant Materials

Five varieties of date palm fruits (BARAKAWI, GONDALLA, KULMA, MISHRIG and WAD LAGGAI) were bought from Bahri market, Khartoum State. Seeds were collected from fruits and germinated in plastic bags for six months at Department of Botany and Agricultural biotechnology, Faculty of Agriculture, University of Khartoum. Leaves samples were collected from ten seedlings and five male and female plants, and then used for DNA extraction.

Genomic DNA Extraction

Genomic DNA was extracted from leaves using CTAB (cetyltrimethyl ammonium bromide) extraction method reported by [32] with slight modifications. Quality and quantity of extracted DNA were estimated by gel electrophoresis $(0.8 \%)$ and Nano-drop. The extracted genomic DNAs were used as a template for PCR amplification.

PCR amplification

Eight primers, six RAPD primers and two ISSR primers were used for amplification and their sequences were listed in Table 1.

Table 1.

\section{Primers used for PCR amplification}

\begin{tabular}{llc}
\hline Primer & Sequences $\left(\mathbf{5}^{\prime} \boldsymbol{\rightarrow} \mathbf{3}^{\prime}\right)$ & $\begin{array}{c}\text { Tm } \\
\text { ( } \mathbf{c})\end{array}$ \\
\hline RD A01 & AGCAGCGCCTCA & 40 \\
RD A02 & GCCAGCTGTACG & 40 \\
RD A21 & GTGACCGATCCA & 32 \\
RD A23 & AAGTGGTGGTAT & 34 \\
ISA02 & GAGAGAGAGAGAGAGAGAC & 57.3 \\
IS-A71 & CACACACACACACACACG & 56.1 \\
OPA02 & TGCCGAGCTG & 34 \\
OPJ-09 & TGAGCCTCAC & 32 \\
\hline
\end{tabular}

PCR amplification was performed with extracted genomic DNA for sex determination using $5 x$ HOT

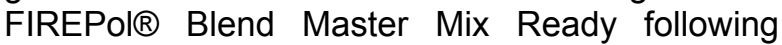
manufacturer's instructions. PCR reaction was 
carried out in $20 \mu \mathrm{l}$ reaction mixture containing $4 \mu \mathrm{l}$ of 5x HOT FIREPol 8 Blend Master Mix Ready, 20 picmole primers, $2 \mu \mathrm{l}$ of genomic DNA and $13.2 \mu \mathrm{l}$ dd $\mathrm{H}_{2} \mathrm{O}$. The PCR reactions were conducted for an initial denaturation at ${ }^{\circ} \mathrm{C}$ for $2 \mathrm{~min}$, followed by 40 cycles of $1 \mathrm{~min}$ at $94^{\circ} \mathrm{C}, 1 \mathrm{~min}$ at $42^{\circ} \mathrm{C}$, and 2 min at $72{ }^{\circ} \mathrm{C}$, and final extension at $72{ }^{\circ} \mathrm{C}$ for 7 min for the following primers (RD A01, RD A02, $\mathrm{RD}$ A21 and RD A23). The PCR reactions were conducted for an initial denaturation at $94^{\circ} \mathrm{C}$ for 2 min, followed by 40 cycles of $1 \mathrm{~min}$ at $94^{\circ} \mathrm{C}, 1$ min at $36^{\circ} \mathrm{C}$, and 2 min at $72{ }^{\circ} \mathrm{C}$, for OPA02 and OPJ-09 primers, $1 \mathrm{~min}$ at $94{ }^{\circ} \mathrm{C}, 1 \mathrm{~min}$ at $53^{\circ} \mathrm{C}$, and $1.5 \mathrm{~min}$ at $72{ }^{\circ} \mathrm{C}$ and final extension at $72{ }^{\circ} \mathrm{C}$ for7 min for ISA02, IS-A71 primers. PCR products were separated by gel electrophoresis on $0.8 \%$ agarose gels, stained with ethidium bromide and visualized with the UV transilluminator.

\section{Results and Discussions}

Due to idiocy, date palm progenies contain equal proportion of male and female plants with no certain way to differentiate male and female plants before flowering which usually takes 5 - 10 years after cultivation [33]. Thus, it is very important to develop some molecular markers for sex determination in date palm at early stages. Molecular markers such as SSR, ISSR and RAPD have been used for sex determination in many plants. These tools will greatly assist breeding programs [34]. The current study is aims to examine the validation of some DNA molecular marker (RAPD and ISSR), which have been used previously on other cultivars. RAPD and ISSR primers used in this study have been used previously by [1], [35] and [36] for sex determination in date palm genotypes. The DNA concentration of 15 date palm accessions ranged from 0.59 to $22.25 \mathrm{ng} / \mu \mathrm{l}$ and purity ranged from 1.01 to 1.87 (Table 2).
In this study DNA was amplified by six RAPD primers and two ISSR primers (Table 1) to check their validation in sex determination of date palm genotypes (three male and female as well as nine unknown) grown under environmental conditions of Sudan.

Table 2.

DNA purity and Concentrations

\begin{tabular}{cccc}
\hline No. & Sample & $\begin{array}{c}\text { Ratio of } \\
\text { A260/A280 }\end{array}$ & $\begin{array}{c}\text { Quantity of } \\
\text { DNA } \\
\text { (ng/ } \mathbf{\mu l} \text { ) }\end{array}$ \\
\hline 1 & M1 & 1.67 & 5.37 \\
2 & M2 & 1.74 & 10.31 \\
3 & M3 & 1.75 & 19.93 \\
4 & M4 & 1.73 & 13.06 \\
5 & M5 & 1.74 & 22.25 \\
6 & F1 & 1.87 & 19.92 \\
7 & F2 & 1.82 & 10.17 \\
8 & F3 & 1.67 & 5.58 \\
9 & F4 & 1.86 & 44.07 \\
10 & Un1 & 1.86 & 19.75 \\
11 & Un2 & 1.81 & 5.78 \\
12 & Un3 & 1.84 & 5.57 \\
13 & Un4 & 1.55 & 1.06 \\
14 & Un5 & 1.78 & 9.91 \\
15 & Un6 & 1.76 & 21.11 \\
16 & Un7 & 1.01 & 0.59 \\
17 & Un8 & 1.76 & 6.35 \\
18 & Un9 & 1.73 & 4.49 \\
\hline
\end{tabular}

$\mathrm{M}=$ Male, $\mathrm{F}=$ Female, $\mathrm{UN}=$ Unknown

The date palm genotypes were subjected to the genomic PCR analysis to identify potentiality of these markers in sex determination. All RAPD primers were produced multiple bands ranging in size from $150 \mathrm{bp}$ to $1300 \mathrm{bp}$ indicating polymorphism among genotypes. The number of amplicon bands varied from 2 to 8 bands per primer

(Table

\section{Number of amplicons of six primers based on RAPD}

Table .3

\begin{tabular}{lcccccccccccccccc}
\hline Primers & M1 & M2 & M3 & F1 & F2 & F3 & U1 & U2 & U3 & U4 & U5 & U6 & U7 & U8 & U9 & Total \\
\hline OPA02 & 7 & 4 & 6 & 4 & 5 & 5 & 7 & 7 & 6 & 6 & 7 & 7 & 7 & 7 & 7 & 92 \\
OPJ-09 & 6 & 7 & 6 & 5 & 4 & 3 & 7 & 7 & 7 & 7 & 8 & 7 & 8 & 6 & 7 & 95 \\
RDA01 & 5 & 4 & 4 & 2 & 3 & 4 & 5 & 6 & 6 & 5 & 6 & 5 & 6 & 6 & 6 & 73 \\
RDA02 & 2 & 3 & 3 & 2 & 2 & 0 & 3 & 3 & 2 & 4 & 4 & 4 & 4 & 4 & 3 & 43 \\
RDA21 & 4 & 5 & 0 & 3 & 4 & 4 & 6 & 6 & 6 & 6 & 6 & 6 & 6 & 6 & 6 & 74 \\
RDA23 & 4 & 3 & 3 & 3 & 3 & 3 & 4 & 3 & 4 & 4 & 4 & 3 & 4 & 4 & 4 & 53 \\
\hline
\end{tabular}

$\mathrm{M}=$ Male, $\mathrm{F}=$ Female, $\mathrm{UN}=$ Unknown 
A conserved fragment of $\sim 450 \mathrm{bp}$ was amplified by OPA 02 primer, while two conserved fragments of $\sim 750$ and 900 bp were amplified by OPJ09 primer in all genotypes (Figure 1.a and b). In addition to that there were extra four conserved fragments amplified by the rest of RAPD primers ranging in size from 200 to $600 \mathrm{bp}$. Of all the RAPD primers four OPA02, OPJ-09, RDA02 and RDA21 were succeed to amplify a unique band in all male genotypes but not in all female genotypes indicating its specificity with male sex in date palm. While two RAPD primers (RD A01and RD A23) could not amplified a unique band in male or female genotypes. RAPD primer OPA02 amplified a male specific fragment of size 1000 (Figure $1 \mathrm{a}$ ), which is consisting with previous obtained results by [1] using same primer. OPJ-09 primer amplified a male specific fragment of size $1000 \mathrm{bp}$ (Figure 1 b) and this was in contrary to results reported by [1].
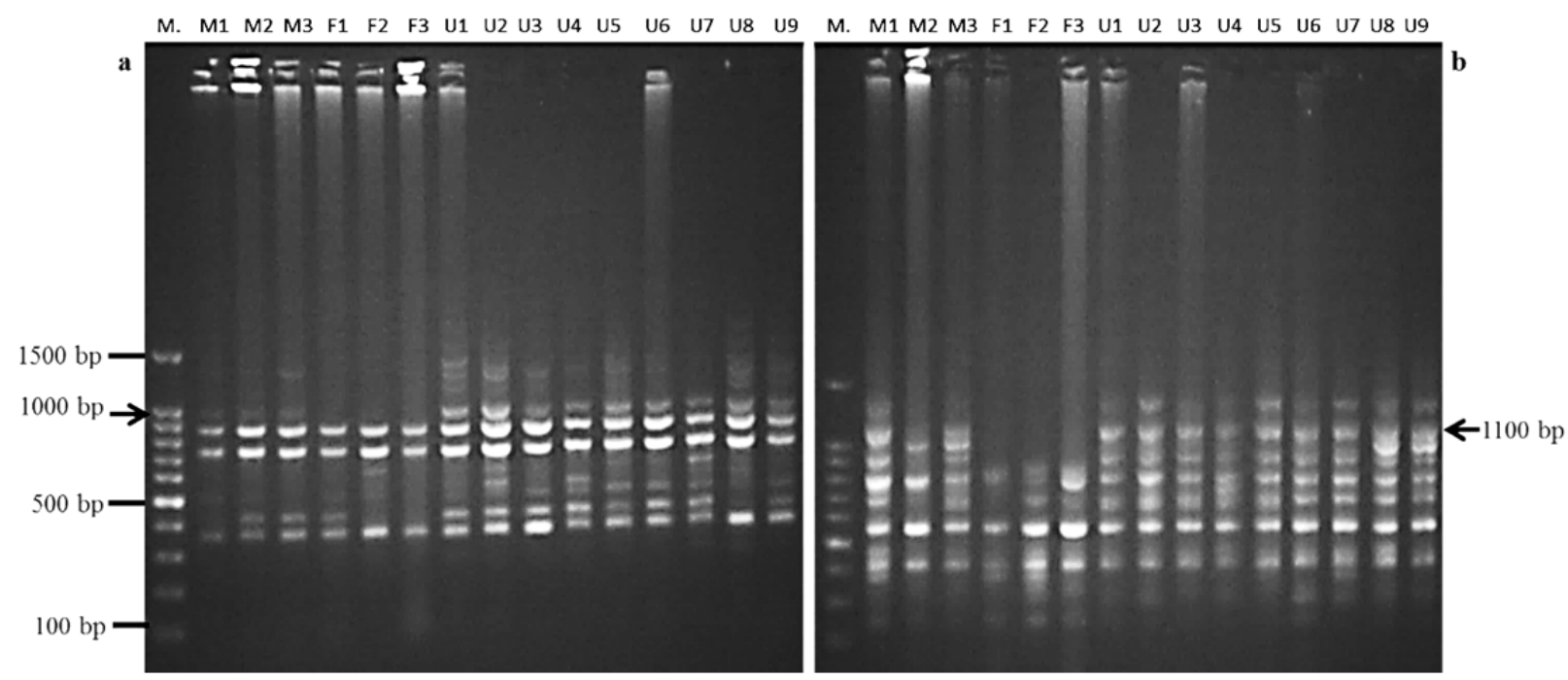

Figure 1. RAPD profiles of male, female and unknown genotype using OPA02 (a) and OPJ- 09 (b) primer .the arrow point a unique band related to Male ,M: Molecular marker (1500 bp), M1-M3: Male genotype, F1-F3: Female genotype,UN1-un9: Unknown genotype.

This is might be due to the genotypes differences. In comparison to reported results using this primer, our results would be better for sex determination in date palm plants. In addition RDA02 primer amplified a male specific fragment of size $1000 \mathrm{bp}$ (Figure. 2 a), this in agreement with the results of previous report in date palm plant [35]. RDA21 primer amplified two male specific fragments of 1000 and 1400 bp (Figure. 2 b). In contrast [35] amplified a band with RDA21 of size $900 \mathrm{bp}$. There is a huge difference in date palm cultivars grown under environmental conditions of Sudan [2]. Nevertheless each single primer from the four valid primers succeeded to amplify male specific fragments in all genotypes under study. Differences in band size comparing with the previous studies maybe due to the differences in genotypes. On the other hand RAPD profile can be vary between laboratories due to the reaction condition [37]. The amount of the DNA template also play important role in generating the banding pattern profile and acquire a reproducible results. Moreover differences in primer concentrations may affect the appearance of some bands [38]. The study failed to generate a specific band that is related to the sex of date palm plant during the usage of the ISSR primers. That was in contrary to what had reported in [36]. Who used the same primer and succeed in obtaining unique bands that are related to male in the case of IS-A17, and female in the case of ISA02. There is a several parameters consider hindrances to ISSR primer. Low temperature has negative impact on the banding pattern leads to appearance of a smear in the gel [25]. In our case the effect of low temperature was observed clearly. 

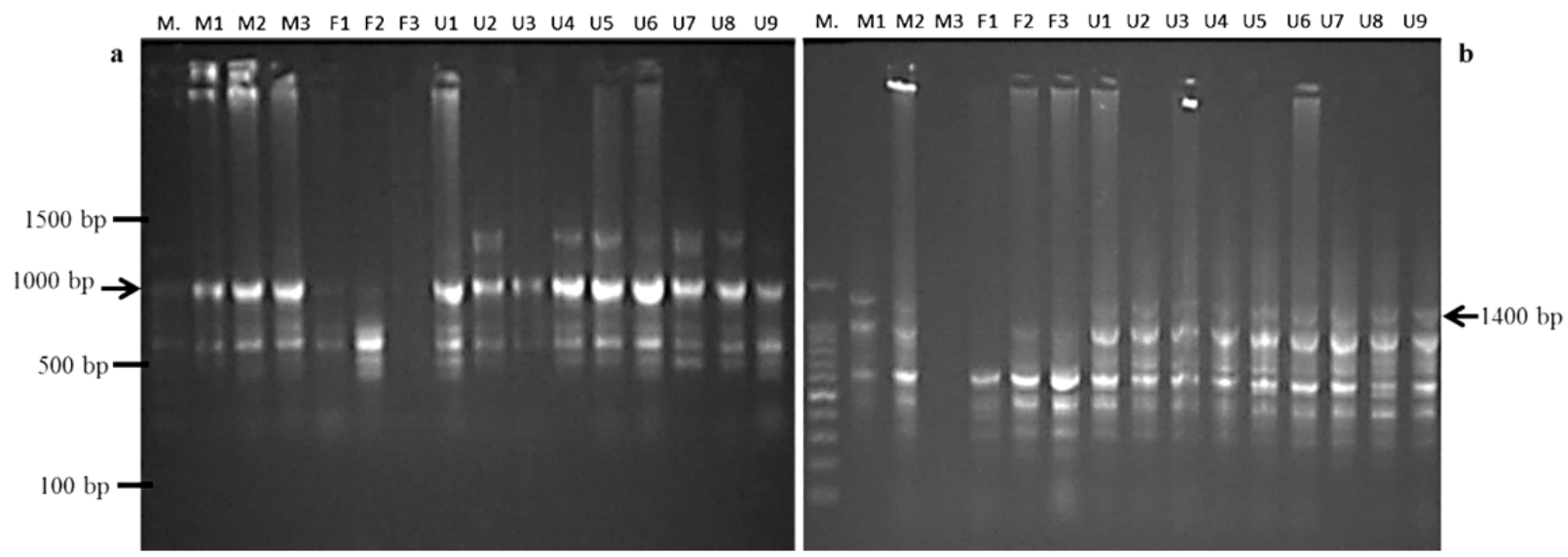

Figure 2. RAPD profiles of male, female and unknown genotype using RD A02 (a) and RDA21(b) primer .the arrow point a unique band related to Male ,M: Molecular marker (1500 bp), M1-M3: Male genotype, F1-F3: Female genotype,UN1-un9: Unknown genotype.

This study represents the first report of using RAPD and ISSR markers for sex determination of date palm plants at the early stage in Sudan. The current study was concluded the validation of four RAPD primers in terms of date palm sex determination. It could contribute to improving genetic breeding program of date palm, leading to enhance quality and quantity of dates. Further study need to be conducted to reveal the sequence of the target fragments and specific primers will be designed for sex determination.

\section{References}

1. Dhawan C., Kharb P., Sharma R., Uppal S. and Aggarwal R. (2013). Development of male-specific SCAR marker in date palm (Phoenix dactylifera L.). Tree Genetics \& Genomes, 9(5), 1143-1150. DOI: $10.1007 / \mathrm{s} 11295-013-0617-9$

2. Maryam M., Jaskani F., Awan S., Ahmad and Khan I. (2016). Development of molecular method for sex identification in date palm (Phoenix dactylifera L.) plantlets using novel sex-linked microsatellite markers. 3 Biotech, 6(1). doi: 10.1007/s13205-015$\underline{0321-6}$

3. Chao C. and Krueger R. (2007). The Date Palm (Phoenix dactylifera L.): Overview of Biology, Uses, and Cultivation. Hort. science, 42(5). https://doi.org/10.21273/HORTSCI.42.5.1077

4. Anwar M. (2006). Phoenlx dactyliferal: A Bibliometric study of the literature on date palm. Malaysian Journal of Library \& Information Science, 11(2).

5. Ezebilo E., Elsafi M. and GarkavaGustavsson L. (2013). On-Farm Diversity of Date Palm (Phoenix dactylifera L) in Sudan: A Potential Genetic Resources Conservation Strategy. Sustainability, 5(12), 338-356. DOI: 10.3390/su5010338

6. Obied, M., Director P.Q.D. and North P.Q.D. (2000). Production and protection of date palms in Sudan, 22-26 Seventh Arab Congress of Plant Prot, Algeria.
7. Siljak-Yakovlev S., Cerbah M., Sarr A. Benmalek S., Bounaga N., Coba de la Pena T. and Brown S. (1996). Chromosomal sex determination and heterochromatin structure in date palm. Sexual Plant Reproduction, 9(3), 127-132. https://doi.org/10.1007/BF02221391

8. Bekheet S. and Hanafy M. (2011). Date Palm Biotechnology. 1st ed. Dordrecht: Springer Netherlands. 9. Tingey S. and del Tufo J. (1993). Genetic Analysis with Random Amplified Polymorphic DNA Markers. Plant Physiology, 101(2), 349-352. DOI: https://doi.org/10.1104/pp.101.2.349

$10 . \quad$ Williams J., Kubelik A., Livak K., Rafalski J. and Tingey S. (1990). DNA polymorphisms amplified by arbitrary primers are useful as genetic markers. Nucleic Acids Research, 18(22), 6531-6535. https://doi.org/10.1093/nar/18.22.6531

11. Sedra M., Lashermes P., Trouslot P., Combes M. and Hamon S. (1998). Identification and genetic diversity analysis of date palm (Phoenix dactylifera L.) varieties from Morocco using RAPD markers. Euphytica, 103 (1), 75-82. https://doi.org/10.1023/A:1018377827903

12. Fahima T., Röder M., Wendehake K., Kirzhner V. And Nevo E. (2002). Microsatellite polymorphism in natural populations of wild emmer wheat, Triticum dicoccoides, in Israel. TAG Theoretical and Applied Genetics, 104(1), 17-29. https://doi.org/10.1007/s001220200002

13. Zhou H., Xie Z. and Ge S. (2003). Microsatellite analysis of genetic diversity and population genetic structure of a wild rice (Oryza rufipogon Griff.) in China.TAG Theoretical and Applied Genetics, 107(2), 332-339. https://doi.org/10.1007/s00122-003-1251-y

14. Uptmoor R., Wenzel W., Friedt W., Donaldson G., Ayisi K. and Ordon F. (2003). Comparative analysis on the genetic relatedness of Sorghum bicolor accessions from Southern Africa by RAPDs, AFLPs and SSRs. Theoretical and Applied Genetics, 106(7),1316-1325. https://doi.org/10.1007/s00122-003-1202-7 $15 . \quad$ Salem H., Ali B., Huang T., Qin D., Wang X. and Xie Q. (2007). Use of Random Amplified 
Polymorphic DNA Analysis for Economically Important Food Crops. Journal of Integrative Plant Biology, 49(12), 1670-1680. https://doi.org/10.1111/j.17447909.2007.00582.x

$16 . \quad$ Urasaki N., Tokumoto M., Tarora K., Ban Y., Kayano T.,Tanaka H. Oku H. Chinen I. and Terauchi R. (2002). A male and hermaphrodite specific RAPD marker for papaya (Carica papaya L.).TAG Theoretical and Applied Genetics, 104(2-3), 281-285. https://doi.org/10.1007/s001220100693

17. Alstrom-Rapaport C., Lascoux M., Wang Y., Roberts G. and Tuskan G. (1998). Identification of a RAPD marker linked to sex determination in the basket willow (Salix viminalis L.). Journal of Heredity, 89(1), 44-49. https://doi.org/10.1093/jhered/89.1.44

18. Vaidya G. and Naik G. (2014). Molecular identification of sex in Simarouba glauca by RAPD markers for crop improvement strategies Biotechnology Reports, 4, 56-59. doi: 10.1016/j.btre.2014.08.003

19. Bouchireb N. (1997). Identification of date palm cultivar using random amplified polymorphic DNA (RAPD). Acta Horticulturae, (448), 88-88. https://doi.org/10.17660/ActaHortic.1997.448.13

20. Bekheet S., Taha H., Hanafy M. and Solliman M. (2008). Morphogenesis of Sexual Embryos of Date Palm Cultured In vitro and Early Identification of Sex Type. Journal of Applied Sciences Research, 4(208), 345-352.

21. EL-Din Solliman M., Mohasseb H., AlKhateeb A., Al-Khateeb S., Chowdhury K., ElShemy H. and Aldaej M. (2019). Identification and sequencing of Date-SRY Gene: A novel tool for sex determination of date palm (Phoenix dactylifera L.). Saudi Journal of Biological Sciences.26 (3), 514523. https://doi.org/10.1016/i.sibs.2017.08.002

22. Al-Mahmoud M., Al-Dous E., Al-Azwani E. and Malek J. (2011). DNA-based assays to distinguish date palm (Arecaceae) gender. American Journal of Botany, 99(1),

https://doi.org/10.3732/ajb.1100425

23. Cherif E., Zehdi S., Castillo K., Chabrillange N., Abdoulkader S., Pintaud J., Santoni S., SalhiHannachi A., Gléminand S., Aberlenc-Bertossi F. (2012). Male-specific DNA markers provide genetic evidence of an $X Y$ chromosome system, a recombination arrest and allow the tracing of paternal lineages in date palm. New Phytologist, 197(2), 409415. https://doi.org/10.1111/nph.12069

24. Solliman M., Al-Khateeb S., Al-Khateeb A. and Allah Adel H. (2014). Sex-determination method for date palm.

25. Bornet B. and Branchard M. (2001). Nonanchored Inter Simple Sequence Repeat (ISSR) markers: Reproducible and specific tools for genome fingerprinting. Plant Molecular Biology Reporter, 19(3), 209-215. https://doi.org/10.1007/BF02772892

26. Gupta M., Chyi Y., Romero-Severson J. and Owen J. (1994). Amplification of DNA markers from evolutionarily diverse genomes using single primers of simple-sequence repeats. Theoretical and Applied Genetics, https://doi.org/10.1007/BF00224530

$27 . \quad$ Dos Santos L., de Oliveira E., dos Santos Silva A., de Carvalho F., Costa J. and Pádua J. (2011). ISSR Markers as a Tool for the Assessment of Genetic Diversity in Passiflora. Biochemical Genetics, 49(7-8), 540-554. https://doi.org/10.1007/s10528-0119429-5

28. Abdel-Mawgood A. L. (2012). DNA based techniques for studying genetic diversity. In: Caliskan M., editor. Genetic Diversity in Microorganisms. InTech

29. Gaafar A., Al-Qurainy F. and Khan S. (2014). Assessment of genetic diversity in the endangered populations of Breonadia salicina (Rubiaceae) growing in The Kingdom of Saudi Arabia using inter-simple sequence repeat markers. BMC Genetics. 15, 109. https://doi.org/10.1186/s12863-014-0109-4

30. Elshibli S. and Korpelainen H. (2007). Microsatellite markers reveal high genetic diversity in date palm (Phoenix dactylifera L.) germplasm from Sudan. Genetica, 134(2), 251-260. https://doi.org/10.1007/s10709-007-9232-8

31. Elmeer K. and Mattat I. (2012). Markerassisted sex differentiation in date palm using simple sequence repeats. 3 Biotech, 2(3), 241-247. doi: 10.1007/s13205-012-0052-x

32. Doyle J. J. and Doyle J.L (1990). Isolation of plant DNA from fresh tissue. Focus. 12:.13-15.

33. Daher, A., H. Adam, N .Chabrillange, M .Collin, N. Mohamed, JW. Tregear and F. AberlencBertossi (2010) Cell cycle arrest characterizes the transition from a bisexual floral bud to a unisexual flower in Phoenix dactylifera. Ann Bot.106:255-266.

34. Sakina K., Arjun S., Jeffrey L. and Mohammed A. (2012). Analysis of molecular markerbased characterization and genetic variation in date palm (Phoenix dactylifera L.) Australian Journal Crop Science , 6(8):1236-1244

35. Ageez, A. and Madbol E. (2011). Identification of male specific molecular markers in date palm Sewi cultivar. Egyptian Journal of Genetics and Cytology, 40(2).

36. Al-Ameri A., Al-Qurainy F., Gaafar A., Khan S., and Nadeem M. (2016) Molecular identification of sex in Phoenix dactylifera L. using inter simple sequence repeat markers. Bio. Med Research International,

$1-5$.

http://dx.doi.org/10.1155/2016/4530846

37. Bardakci F. (2001). Random Amplified Polymorphic DNA (RAPD) Markers. Turkish Journal of Biology, 25(2), 185-196.

38. Munthali M., Ford-Lloydand B., Newbury H. (1992). The random amplification of polymorphic DNA for fingerprinting plants. Genome Research, 1(4),274276. 